\title{
Examining the use of picture books in preschool education institutions
}

\author{
Atiye Adak Özdemir ${ }^{\text {a }} 1$ (D), Filiz Hıdır ${ }^{\text {b }}$ (iD), Burcu Özdemir Beceren ${ }^{\text {c (iD }}$ \\ ${ }^{a}$ Atiye Adak Özdemir, Pamukkale University, Denizli, 20175, Turkey \\ ${ }^{b}$ Filiz Hidir, Pamukkale University, Denizli, 20175, Turkey \\ ${ }^{b}$ Çanakkale Onsekiz Mart University, Çanakkale, 17100, Turkey
}

APA Citation:

Adak Özdemir, A., Hıdır, F., Özdemir Beceren, B. (2019). Examining the use of picture books in preschool education institutions. Journal of Language and Linguistic Studies, 15(2), 535-559.

Submission Date:11/11/2018

Acceptance Date:24/01/2019

\begin{abstract}
The present study aims to examine the use of picture books in preschool classes. Case Study, a qualitative research method, was employed as the research method. The data were collected through video recording, semistructured interviews, and documents. They were analyzed by means of document and descriptive analysis techniques. The research findings revealed that the books in the classes were generally composed of the picture books in the form of series and fairy tale books. Teachers participating in this study thought that books were not sufficient in most classes and that in addition to the books present in the classes, there should be more books related to science. The research findings showed that when children are read informative picture books, they display more distracted behavior compared to when narrative picture books are read. However, when examined in general, distracted behavior by children while the teacher reads were understood to be associated more with the strategies that the teacher uses while reading. The most remarkable finding of the study was that the teachers made a limited eye contact with the children while story reading, they did not adjust their tones according to the characters and carry out an activity except asking questions about the story in the post-story reading process.
\end{abstract}

(C) 2019 JLLS and the Authors - Published by JLLS.

Keywords: picture book; preschool; children; teacher; story reading

\section{Introduction}

The concept of children's literature developed on the basis that childhood is a special period at the beginning of the 17th century (Tüfekçi-Can, 2014). Products of children's literature developing awareness about social and cultural values and beliefs in children (Garzotto, Paolini \& Sabiescu, 2010; Saracho \& Spodek, 2010) may support learning in many areas of teaching while chosen according to the teaching targets in that area such as literacy-writing, language, science (Goins, 2004), geography (Hannibal, Vasiliev \& Lin, 2002), mathematics (Keat \& Wilburne, 2009) and social-emotional features (Sackes, Trundle \& Flevares, 2009). Preschool children's books encompass books prepared for children aged 0-7 years (Ural, 2013). For children in the preschool period, books with less writing and more pictures are recommended (Bailey, 2009). In the relevant literature, for preschool children's books generally the terms story book and picture book (Temizyürek, Şahbaz \& Gürel, 2016; Y1lar, 2015) appear to be used. Picture books are children's first experience with literature (Tuğrul \& Feyman, 2006). Picture books on one hand support children's acquisition of knowledge and

\footnotetext{
${ }^{1}$ Corresponding author. Tel.: +90-506-248-4210

E-mail address: aadak@pau.edu.tr
} 
comprehension skills (Mantzicopoulos \& Patrick, 2011) and on the other hand contribute to children's language development and vocabulary and support their understanding of themselves, gaining socialization, artistic and cultural experiences, and enjoyment (İpek-Yükselen, 2013; Ural, 2013).

\subsection{Literature review}

Picture books written for children in the preschool period can be investigated in two categories of fictional-narrative and non-fiction-informative. While picture books written with the aim of fulfilling children's desire and need to learn about certain topics, events, concepts, or situations (Tüfekçi-Can, 2014) and increasing children's knowledge about people, objects and events (Reese \& Harris, 1997) are called informative books, picture books without a direct teaching aim are called fiction-narrative books. There are some differences between the informative and fiction-narrative books in terms of form and content and these differences affect the language and reading styles of readers (Torr \& Clugston, 1999). When examined in terms of form and content, informative books commonly contain explanatory-descriptive text (Tüfekçi-Can, 2014) and generally the events and characters are real, while narrative-fiction books generally contain imaginary events and characters (Rodriguez, 2013). Research completed with preschool teachers found that teachers are limited in terms of type to the books they can use in class and they read more narrative books compared to informative books in classes (Pentimonti, Zucker \& Justice, 2011; Yükselen, Yumuş \& Işık, 2016). In the early childhood period, presentation of informative books in addition to story books to children will make it easier for children to understand these types of text in future years (Duke \& Kays, 1998). There are a variety of differences between informative and story books in terms of expression, use of literary language and presentation of events (Donavan \& Smolkin, 2001; Torr \& Clugston, 1999):

Narrative books use the past tense while informative books use the timeless present tense.

Narrative books have an event pattern in the form of introduction, complication, crisis, and solution.

Informative books involve concerns about classifying events according to general features.

Narrative books focus on literature elements (sound repetition, repetitions, metaphor) while informative books focus on technical terms and elements (synonyms, antonyms, analogies).

Narrative books may be real or imagined. Additionally, these books contain non-technical language used in daily life.

\subsubsection{Research into picture books in Turkey}

The book called Hedgehog Tale written in 1974 by Can Göknil is accepted as the first picture book aimed at preschool children in Turkey (Gönen, 2013). From this date on, with the acceptance of children's rights and focus on the child in education, both royalty and translated children's books increased in number and in parallel research related to children's picture books increased. This research appears to be about topics like investigation of the internal and external structural features of children's picture books (Dağlığlu \& Çamlıbel-Çakmak, 2009; Dilek, 2017; Gönen, 1993; Gönen, Uludağ, Findık-Tanrıbuyurdu \& Tüfekçi, 2014; Işıtan, 2016;), investigation in terms of concepts (Kılıç, Değirmenci, Ünsal \& Uyanık-Balat, 2017) and values (Körükçü, Acun-Kapıkıran \& Aral, 2016) contained, opinions of preschool teachers about book selection and children's books (Yükselen, Yumuş \& Işık, 2016) and reading methods and strategies for children's books for preschool teachers in class (Deniz, 2018; Şimşek, 2017).

\subsubsection{Story reading activities}

Book reading activities in preschool education classes are generally completed by the teacher reading the book using a loud voice. When children hear books read aloud, they hear the sounds of the words, recognize the sounds of the words, learn the meaning of the words through the pictures 
included in the story and begin to notice how these words are represented in writing. In this way, the motivation of children who love books to read is increased (Beaty, 2009). In Turkey, the importance of reading books to children is emphasized in the preschool education program guidebook (MEB, 2013) with teachers performing reading activities in class encouraged to chat with the children after reading and ask questions about the main event in the story, characters, problems created in the story and about introduction, development and outcomes. Additionally, the necessity to introduce children to elements like basic features of picture books such as the pictures, writing, color, and size along with discussions about authors and illustrators is mentioned (MEB, 2013). Book reading activities without any planning or preparation may be enjoyable in preschool education classes; however, the instructional contribution to the children will be limited (Kindle, 2001). Before teachers begin storyreading activities in class, they should read the chosen book once themselves, develop an understanding about how to present it to the children, then read the book aloud themselves and note the elements they wish to emphasize to the children (comic words, etc.). When reading the content of the book, if the teacher transforms words like slammed, sneezed, snored into actions while reading (sound of sneezing, sound of slamming, making a snoring sound) it will increase children's attention. At the end of the story, simple questions should be asked related to the story (what character did you like most, do you remember what the sheep said?). Additionally, it is important to use the topic, concept, character or locations in the story in other activities (games, art, etc.). Reading the story in individual or small groups and repeatedly reading the book is important in terms of children gaining more benefit from story-reading activities (Beaty, 2009).

Teachers make the decision about what book to read and how it is read in preschool education classes (Kindle, 2001). Research has shown that preschool teachers have limited knowledge about diverse types of children's books (Bağc1 Ayrancı \& Aytaş, 2017), and additionally their duration in the profession was shown to be effective on the selection and reading of picture story books by preschool teachers (Hsiao \& Chang, 2016). In the relevant literature there are research findings showing that different strategies are used during and after reading by teachers performing book reading activities in preschool education classes (Bay \& Çetin, 2014). Research findings in the context of book reading in preschool education classes have revealed differences in the strategies and methods used even if the teacher reads the same books to different classes, with differences in terms of the language and early literacy skills obtained from these readings by preschool children (Kindle, 2001; Wasik \& Bond, 2001) and their participation in the story reading process (Moschovaki, Meadows \& Pellegrini, 2007). Research results show that teachers use different strategies for book reading processes in preschool education classes. These differences are revealed in the context of including motivating activities before reading the book (poems, finger games, chats, etc.) (Tarım, 2015), interacting with the children while reading (Ergül, Akoğlu, Sarıca, Tufan \& Karaman, 2015; Şimşek, 2017 \& Tetik, 2015) and asking the children questions after reading (Işıkoğlu, Erdoğan \& Akay, 2015; Işıkoğlu, Atan, Asar, Mumcular, Yüce, Kiraç \& Kilimlioğlu, 2016). Reading/sharing of picture books by adults (teacherparents) and strategies used in this sharing are associated with the language and literacy of children (Zucker, Cabell, Justice, Pentimonti \& Kaderavek, 2013) and their received and expressive language skills (Deniz, 2018; Gönen, 1989; Robertson \& Reese, 2017; Şimşek, 2017).

As children in the preschool period do not know how to read, parents and teachers take on a mediating role between books and children. Correct selection of books by parents and teachers (Çer, 2016; Sever, 2003) and correct presentation of books to children give the message that books are sources of entertainment and knowledge and contribute to a love of books (Gönen, 1993; Ural, 2013). In Turkey in recent years there has been an increase in research about reading methods and strategies for teachers of preschool education classes and it is understood that teachers are mainly assessed when reading books they have chosen. In this research, two different children's book types (informative and 
story book) were given by the researchers and teachers were requested to read them to the class. Additionally, distribution of book centers in classes were investigated according to book type and the aim was in-depth research by inquiring about teacher's opinions of children's books. In this context, it is considered this research will contribute to the relevant literature in our country.

\subsection{Research questions}

In line with the information above, it can be said that picture books provide significant contribution to children; however, this contribution is closely related to the teacher's thoughts about the variety of books provided in the classroom and about the contribution of these books to children and how the teachers read the books to the class. In this context, this research aimed to seek answers to the question; how are picture books used in preschool education classes? Within the framework of this main question, other questions included in the scope of the research are stated as follows:

1. What are teachers' opinions about children's books?

2. What types of books are present in preschool education classrooms?

3. How do teachers read books in class?

\section{Method}

The present study adopted the case study design of the qualitative research methods and the participants were determined through the purposive sampling technique. Case studies are an appropriate pattern for cases investigated in the context of real life and more than one data source is present (Merriam, 2013).

\subsection{Participants}

In this study, preschool teachers and 4th class preservice teachers were given books by the researchers and required to read the books while being recorded on video. As a result, firstly research permission was obtained from the Provincial Directorate of National Education to perform the research in Denizli provincial center. Then schools were visited, and the study was explained, and the study began with 16 teachers who volunteered to participate. Of these 16 teachers, 10 answered the interview questions, and accepted recording of all books in the classroom; however, they did not accept video recording of the book reading activity. The remaining 6 teachers both filled in the interview form, accepted recording of all books in the classroom and video recording of the book reading activity while reading books provided by the researchers.

The study group consisted of sixteen preschool teachers working in pre-school education institutions in Denizli city center and six 4th grade prospective preschool teachers who were doing their internship in the classroom of these teachers. All teachers had a bachelor's degree, and they had at least 5 years of teaching experience and were working with children at five years old. All teachers completed the interview form prepared by the researchers and the names of the books in the book center of their class were recorded. Story reading work were carried out with six teachers (among sixteen teachers) and six prospective teacher (were doing their internship in the classroom of these teachers) who volunteered to participate in the study. The purpose of this study was not to observe the prospective teachers but to examine the children's participation in the reading of a different adult rather than a teacher who knew them. For this reason, the expression "prospective teacher" was not used in the text. In Table 1, the teachers and the research classes were indicated with codes. The code "CR1, T1, $15 \mathrm{~min}, 10 \mathrm{CHN}$ " refer to "The first(1st) class, the first(1st) teacher, 15 minutes reading 
time, and the number of the children in the group was 10 ". During coding T1 indicates a class teacher while $\mathrm{T} 2$ is a preservice teacher.

\subsection{Instrument $(s)$}

Three different data collection instruments were employed in the study.

Interview form: The interview form was developed by the researchers to determine the opinions of the teachers on picture book selection for their classes, the children's interest in the storybooks and their practices regarding the storybooks in their classes. The form was arranged in line with opinions from three experts in the field. The forms were filled out in written.

Documents: A list for the picture books in the classes was prepared and examined in terms of their genre.

Video recording: The researchers designated 11 books (6 narrative-fictional / 5 informational), all of which were composed of the picture books. The fundamental criterion for book selection was to be narrative-fictional or informational. Each class had 4 books including at least an informational and narrative-fictional book. The prospective teachers and the class teachers read two books for each and their readings were recorded. There was no guidance as to which books would be read by the prospective teacher or the class teacher, and when and how the reading would be practiced. The information about the picture books used in the story reading work is indicated below.

-Burcu and Berk: Our emotions / Burcu and Berk: Safety looking out for yourself: Defne Ongun Müminoğlu (author)

-The windy day / On the lake / The rainy day / How high is the sky? / How deep is the sea?: Anna Milbourne (author)

-Tali becomes self-confident / Tali Stands up for Himself: Berrin Göncü Iş̧koğlu (author)

-Alper: I want to win all the time/ Burcu: No one wants to play with me: Nurşen Şirin (author)

\subsection{Data analysis}

The data obtained from the interview questions were analyzed through descriptive analysis and content analysis technique. In the analysis stage, firstly responses by teachers on the interview form had statements selected as key-focus by the researchers and responses in the form of words/short sentences were recorded sequentially in an excel file. Responses related to each other were grouped using color codes. The responses of teachers were read once by the researchers. On the second reading, statements emphasized by teachers were written one after the other (words-sentences). Later these statements were grouped reflecting common features. Finally, categories/themes encompassing statements in each group and sub-categories within these categories were created (Weber, 1985; cited Yıldırım \& Şimşek, 2003).

The lists of the books in the classes were reviewed twice. While the researchers categorized the books as individual books (books which are sold as a package with 6-50 books covering the books of one or more authors for a specific purpose) in the first review, they grouped them as tale, story, books on Atatürk, books on cartoon characters in the second review. Video contents were monitored by two researchers as they were (order of the seating, position of the teacher, dialogues, attitude of the teacher in reading, number of the children). Later, the contents were analyzed based on the descriptive analysis technique and, they were grouped and tabulated by common consent under the headings of pre-story reading, while-story reading and post-story reading in the related literature. Then the tables were summarized and presented. 


\section{Results}

In this part, the books in the preschool classes, the opinions of the teachers on the picture books and teacher story reading practices were presented separately.

\subsection{Findings about the books in the research classes}
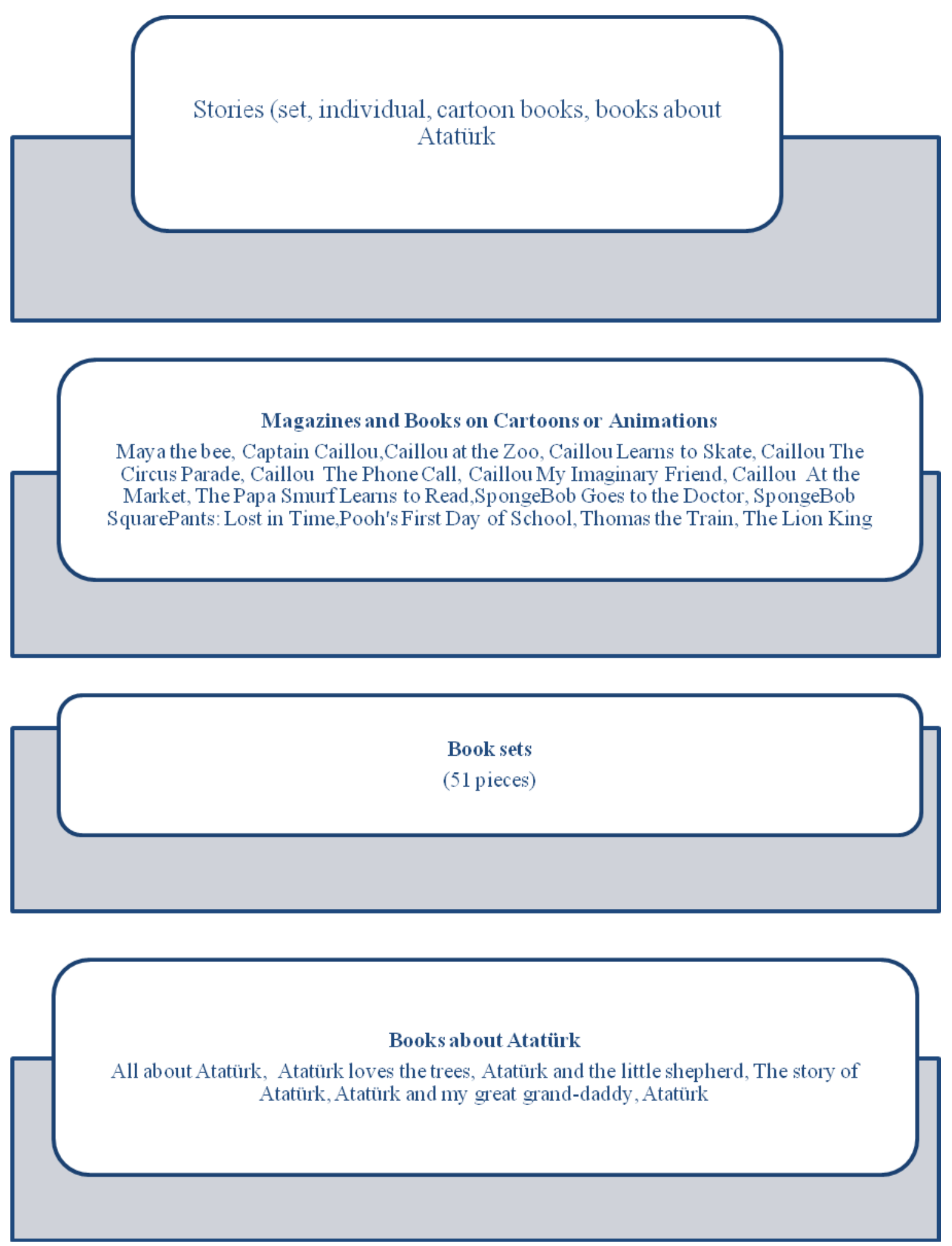

Figure 1. Picture storybooks found in classes 


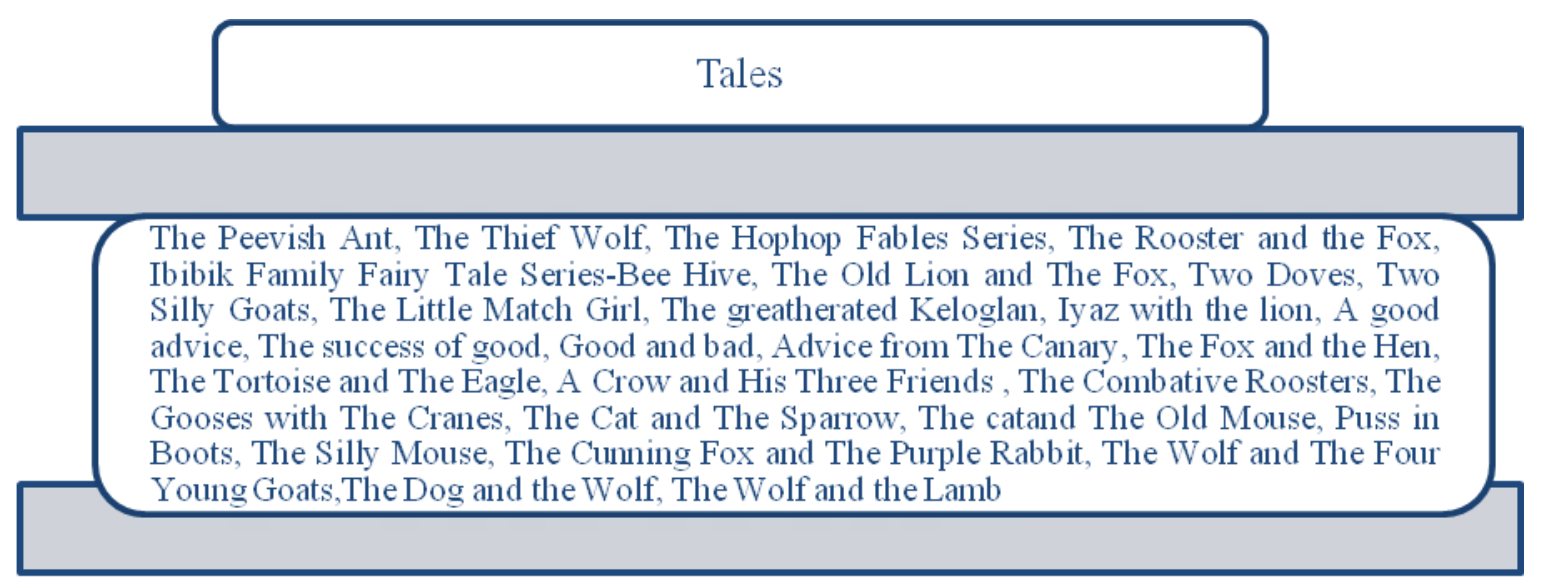

The Chicken with Golden Eggs, The Storks (Andersen Tales), The Monkey and The

Fisherman (Aesop's Fables), Short Tales, The Milkmaid and the Pot of Milk (Lafontaine),

Aesop's Fables, The Pied Piper of Hamelin,Rumpelstiltskin, Crazy Boy, A Smith and His

Dog, The Lighthouse, The Mermaid, The Tales of the Mermaid, The Little Elephant, The Boasting Rabbit, The lion in Love, The Golden Goose, The Deer with Golden Hooves, The Bremen Town Musicians, The Little Mermaid, The Happy Animals Tale Series, The Rabbit and The Tortoise

The Winter Squash, The Dove and the Ant, The Cunning Rabbit and The Donkey, The Trees and The Axe, The Greedy Dog, The Bulbul and The Bat (Aesop), The Boasting Rabbit, The Magic Tales, The Brave Little Tailor(Brothers Grimm), The Stingy Rabbit, The Farmer and His Dog (Aesop), The Roasters, The Talkative Turtle, The Lion and The Deer, The Chunking Rabbit, The Sun and The Tortoise (La Fontaine), The Hidden Treasure (Aesop's Fables), The Luck Child (Brothers Grimm), The Cuckoo and The Canary

Gulliver, Gulliver in the Country of Giants, Fables, The Magic Beans, Snow White, The Magic Forest Tales, The Greedy Karabaş, The Covetous Karabaş, Magic Chest, Cinderella, Thumbelina, Tom Tumb, The intuder, The Lion and the Gnat,The Frog Who Wished to Be as Big as the Ox (La Fontaine), The Lark and Her Young Ones, The Ape and the Dolphin(La Fontaine), The Heron and the Fish,The Bat and The Weasels (Aesop), The Liar Shepherd, The Three Naughties, Three Sisters Sheep

Award-w inning 1 ales selies- the Nanghty Kaboits, the woll and the Fox, the Lion and The Mouse, The Brave Little Tailor, The Lion and the Gnat, The Fox and The Woodcutter, The Fox and The Stork, Sleeping Beauty, The Fox and the Crow, The GoodHearted Giant, The Golden Fish, Little Red Riding Hood,The Rooster and the Fox, The Sleeping Princess,Ali Baba and The Forty Thieves, The Morals, Keloglan, Keloglan and Ali Cengiz, Keloğlan and His Friend, Keloglan and The Giants, Keloglan and The Country Girl, Keloglan and His Lambs

Keloglan with speaking cloud, Keloglan and the gifted rabbit, Keloglan and the Sultan's daughter, Keloglan's happiness, The donkey in lion's boots, Akşah and Karasah, Rabbit and the turtle,Puss in boots, Idiot wolf, Cicada with ant, Aladdin's magic lamp, 7 tales in 7 days, Alice in wonderland, The horse, The fox and wolf, The bulbul with bat, Mouse and turtle, Mouse with the marten, Friend of the little mouse

Figure 2. Tales found in classes

Figure 1 presents the details of the picture books in the preschool classes where the research is conducted. Since they were directly referenced by the publishing houses, the names of the books in the set-series (of a particular author, multi-author or collective) were not specified. A total of 51 sets of books were reached. While the book sets were mainly about values (responsibility, cooperation, 
sharing, honesty, humility, etc.), problems encountered in everyday life, a limited number of sets (9 pieces) included books on concepts, science and nature. The book sets ranged from 6 to 50. Figure 2 represents the tales found in classes. The presence of books and tales which are written by a certain author or multiple writers by considering specific concepts and subjects in the classes directly suggest that the teachers consider the content (subject) characteristics of books rather than literary, aesthetic, language, and visual features.

\subsection{Findings about the teachers' opinions regarding book selection, the features of the picture books and story reading practices}

\subsubsection{The sufficiency of the available books and other books that can be added to the library}

In answer to the questions "are there sufficient books in your classroom? would you like other books in your classroom?," five teachers (T1, T4, T9, T14, T16) considered they had sufficient books in their classroom. When teacher's responses are evaluated, different themes were determined. These are

Related to science (scientific books, books about science and space, encyclopedias, books related to science and nature, books related to science and mathematics). Eight teachers responded based on this: (T3, T5, T7, T10, T12, T8, T11, T2)

Books related to certain days and weeks: (T15)

Books related to behavior and value education: $(\mathrm{T} 10, \mathrm{~T} 2)$

Books with different forms and functions (interactive, large size/large pictures, moveable, different shapes). Three teachers responded based on this theme: (T6, T7, T11)

It is noteworthy that teachers requested books containing information about certain topics in addition to the books available to them. Books included in the first three themes are topic-focused, while books in the fourth theme are focused on form and function characteristics.

\subsubsection{The criteria taken into consideration in book selection}

Except for one teacher (T16, I did not choose the books), all the teachers expressed that while some books were chosen by the previous teachers, others were chosen by themselves.

When responses to the question of what criteria was used to choose the books in the classroom are assessed, four different themes were obtained. These are:

Topic and content of the book (language used, instructional, topic, content, appropriate for the program): (T1, T2, T3, T4, T6, T7, T8, T9, T14, T15)

Visuals: (T1, T2, T3, T4, T5, T7, T8, T9, T11, T14, T15)

Form characteristics (page numbers, paper quality, size of the book, size of text, writing-picture ratio): T1, T2, T3, T4, T5, T6, T7, T9, T11, T14, T15

Development features of children (age, development): (T1, T2, T5, T7, T9, T10, T11, T13, T14, T15)

\subsubsection{The children's favorite books according to the teachers}

According to the teachers, the preschool children love tales (classics, fables, tales on supernatural powers, didactics, the ones having topics close to everyday life) and books which include examples of their own lives and they can transfer to their daily lives (tooth brushing, animals, germs, babies), and the books on scientific subjects, sky, animals, and natural events. 


\subsubsection{The contributions of the books to the children according to the teachers}

In answer to the question of "according to you, what contributions do children receive from children's books?" two different themes were obtained. The first of these is contribution to development while the second is called love of books. The development contribution theme contains two sub-themes of social emotional development and language and cognitive development. This finding shows that teachers focus more on ensuring contribution to children's development with children's books.

Promoting socio-emotional development: empathy, social relations, self-confidence, selfexpression, learning the rules for classroom and society (T1, T2, T4, T5, T6, T7, T8, T9, T10, T11, $\mathrm{T} 12, \mathrm{~T} 13, \mathrm{~T} 14, \mathrm{~T} 15, \mathrm{~T} 16)$

Supporting language and cognitive development: language development, gathering attention, promoting attention duration, vocabulary knowledge, eloquence, learning, imagination, mental development, supporting comprehension and narrative skills, problem solving (T1, T2, T4, T5, T6, T7, T8, T9, T10, T11, T12, T13, T14, T15, T16)

Creating a love of books: (T4)

\subsubsection{Teachers practice of story reading activities in their class (according to their opinions)}

The answers to the question of how they practiced story reading activities in their class revealed that they had a conversation with the children about the subject of the story, read a poem about the subject, told nursery rhyme or played finger game, asked them to guess the title of the book and the characters in the book in the pre-story reading process. It was understood that the teachers used different techniques and posed questions to the children in the while-story reading process. Finally, they expressed that they asked questions about the story, asked them to tell the story and acted it out / dramatized in the post-story reading procedure.

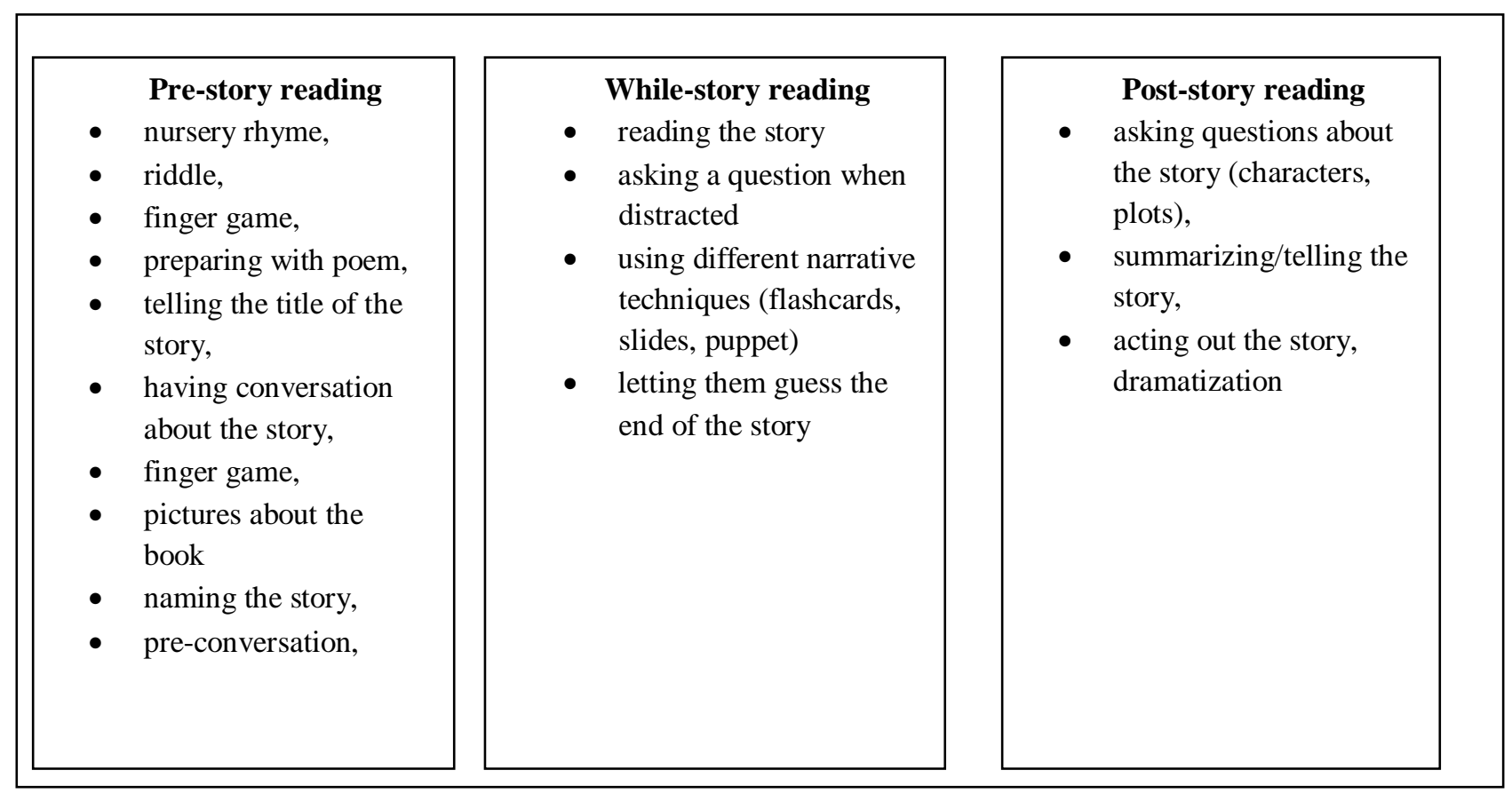

Figure 4. Teachers' opinions on story reading practices 


\subsubsection{Findings about teachers' story reading practices (according to video recording)}

The story reading videos of the teachers were presented in Table 1 by grouping as pre-story reading, while- story reading and post-story reading based on the literature of the story reading models and post-story reading activities. These three themes were determined by noting the classifications in the relevant literature (Işstan, 2013).

Table 1. Findings obtained from the story reading videos in the classes

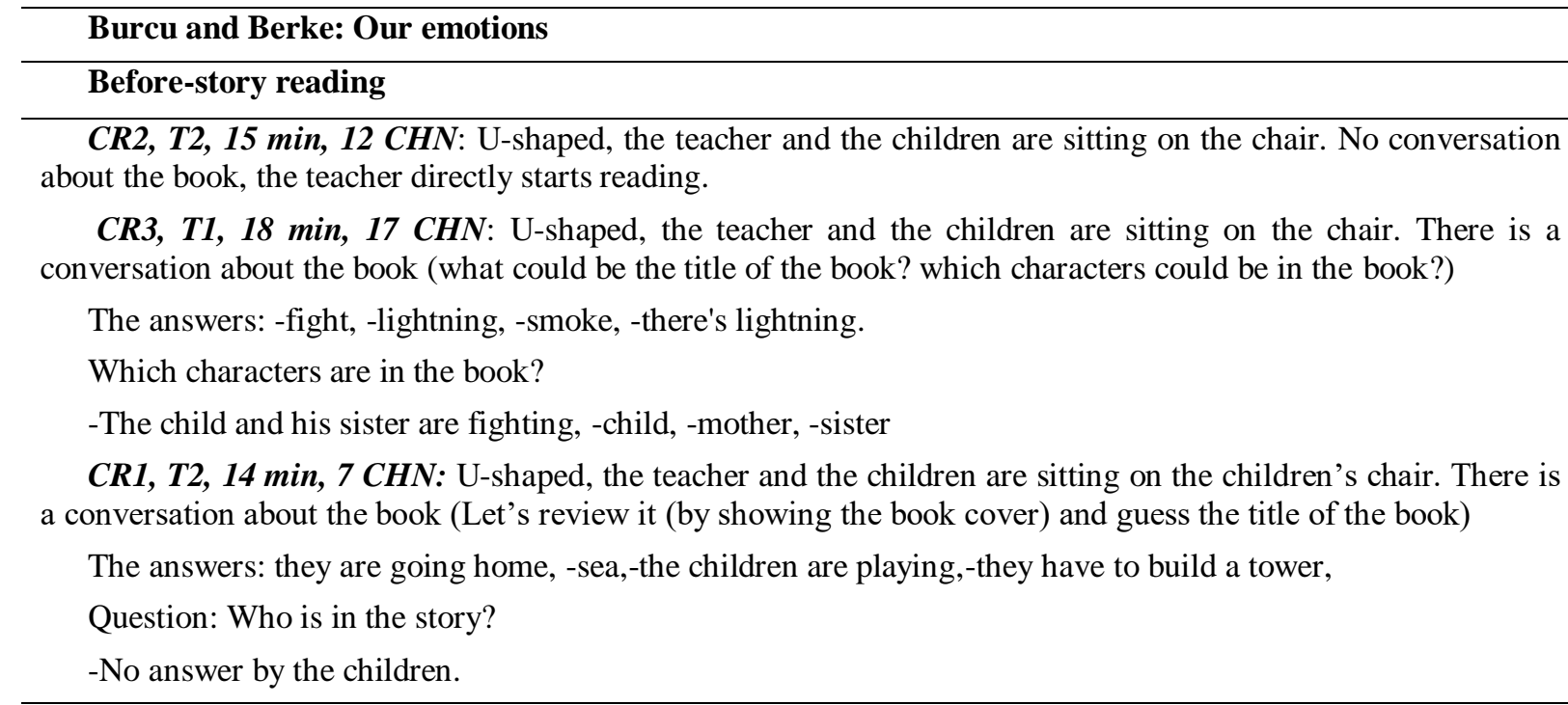

While-story reading

CR2, T2, 15 min, 12 CHN: The teacher reaches her arm out in the direction of her hand with the book, leans forward and reads the book. She occasionally shows the pictures. Extremely limited eye contact, her tone adjusts according to the characters and the topic, limited use of gestures and mimics.

Question: What does a veterinarian mean?

The answers: He heals animals.

The teacher continues to read without commenting. Some children are lying on the floor, some are talking to each other. The teacher firstly tries to direct the children to the book by drawing attention to the picture on the page (Look! how funny the dog looks like) She then warns the children by calling their names stressed (Ali! Kerem! Kıvanç!).

CR3, T1, $18 \mathrm{~min}, 17 \boldsymbol{C H N}$ : The teacher reaches her arm out in the direction of her hand with the book, leans forward and reads the book. She occasionally shows the pictures. Extremely limited eye contact, her tone does not change according to the character or the topic, no use of gestures and mimics. She continues to read with a flat, unstressed, and distorted diction.

The children approach her to see the pictures. Some children are sitting in the chair to stand up, some are moving with the chair.

The teacher warns them: Duru, could you go back? - could you sit down? -please, do not approach- please, do not stand up- do not ripple in the chair...

CR1, T2, $14 \min , 7 \boldsymbol{C H N}$ : The teacher firstly shows the page she will read to the children, then reaches her arm out in the direction of her hand with the book, leans forward and reads the book without an eye contact. She does not use gestures and mimics, and her tone is unstressed.

Question: What do you think they can do to make their mothers happy?

The answers: They may wipe the dog, - it should be cleaned.

The children are either lying, standing, or moving away from the area.

The teacher's reaction: Bedirhan! Buse, could you sit down! Bedirhan, why are you making me sad? Kerem! Mmmm, look how happy they are when they see the dog clean (He is showing the picture) Ömer, come here! 


\begin{abstract}
After-story reading
CR2, T2, $15 \mathrm{~min}, 12 \mathrm{CHN}$ : The teacher asks a question "Did you have such feelings?"

The answers:-When I squeezed my hand -I'm afraid of the dark -I'll be happy when I see a rabbit- I'll be happy when I surprise my mom- I'll be happy when I find a dog -I'll be happy when I get a present for my mom on Mother's Day.
\end{abstract}

CR3, T1, $18 \mathrm{~min}, 17 \mathrm{CHN}$ : There is no post-reading activity.

CR1, T2, 14 min, 7 CHN: The teacher asks a question (What does the story tell?)

- Berk felt sad.

-Why?

-Her mother was angry

-Why was she angry?

-Because he painted the dog.

How high is the sky?

Before-story reading

CR4, T2, 13 min, $8 \boldsymbol{C H N}$ : The teacher is in her chair. The children are kneeling one after the other a bit away from him. No conversation about the book (With an expression 'I'll read a book, let's see what you've got to read", he starts to read.) They are looking at her and the book silently.

CR3, T1, $10 \mathrm{~min}, 17 \mathrm{CHN}$ : U-shaped, the teacher and the children are sitting on the chair. There is a conversation about the book (in your opinion, what could be the title of the book? which characters could be in the book?)

The answers: - pengu -pengus -flying pengu -kangaro -funny pengu (he repeats each answer loudly) penguin -birthday -storks

CR2, T2. $12 \mathrm{~min}, 12 \mathrm{CHN}$ : U-shaped, the teacher and the children are sitting on the chair. There is a conversation about the book (in your opinion, what could be the title of the book? which characters could be in the book?)

The answers: -flying penguin, penguin looking for help, penguin

While-story reading

CR4, T2, $13 \mathrm{~min}, 8 \mathrm{CHN}$ : The teacher reaches her arm out in the direction of her hand with the book, leans forward and reads the book. She does not show the pictures. Extremely limited eye contact (she shortly looks at them when the reading is over), her tone changes according to the character and the topic. No use of gestures and mimics. They approach her to see the pictures and try to get ahead of each other.

The teacher: Do not approach me!

After the first page, she asks how high the sky is.

The answers: too much, as high as the clouds, smoke.

Question: What will Pipkin get on with the astronaut? -the rocket

Question: Where will the rocket go? - to the sky

CR3, T1, $10 \mathrm{~min}, 17 \mathrm{CHN}$ : The teacher holds the book a bit away from herself, leans towards one side and continues to read without an eye contact; she sometimes shows the pictures, does not change her tone according to the characters and does not use gestures and mimics. She has a flat and unstressed diction and there is a problem with the diction and pronunciation. The children are talking to each other, the chairs are moving back and forth.

- Teacher! Mustafa went forward. Some children approach her to see the pictures.

- Teacher: Dilruba! Go back Mustafa!

Question: What could have happened later? (The page where Pipkin meets the astronauts)

The answers: he flew up - he went to Antalya- he went to Bursa- he went to the sky by shambling.

Who can tell what could have happened later?

The answers: (The child is next to the teacher, she is holding the book and it is closed.)- they could have gone home. - they went into space, they saw the earth, the planets, and the stars. - they were scared and then came home. 
CR2, T2, $12 \min , 12 \boldsymbol{C H N}$ : The teacher holds the book open to them in her lap. She leans over the book, looks at the children before a new page, bends back again to read the other page.

Question: (After reading the first page) she asks what could have happened later.

The answers: he went to the sky - he flew up (the children continue to ask for the floor, but she maintains to read by ignoring them.)

Question: After reading the page where Pipkin gets on the rocket, she asks what could have happened later.

The answers: - they went to space, -they went to the moon.

Question: What was Pipkin's response? How high was the sky?

The answers: his dad bought a plane and he learned to fly it.

After-story reading

CR4, T2, 13 min, 8 CHN: The teacher asks a question "What does Pipkin most wonder?"

The answers: -how high is the sky? -the sky sky is.

The teacher: The sky is the atmosphere we breathe, Pipkin does not worry about it, he wonders how high the

Question: Well, did he find how high the sky was? (She responses herself: partially)

CR3, T1, $10 \mathrm{~min}, 17 \mathrm{CHN}$ : There is no post-reading activity.

CR2, T2, 12 min, 12 CHN: Question: What was Pipkin wondering? -how high the sky was

Question: Who were the characters in the story?

Ali! Berk! (she warns the boy talking with his friend) The answers: -flying up -higher than clouds, to the space- stork and its mother (they are talking to each other.)

\begin{tabular}{l} 
The windy day \\
Before-story reading \\
\hline $\boldsymbol{C R} 1, \boldsymbol{T 1}, 12 \mathrm{~min}, \mathbf{1 1} \boldsymbol{C H N}$ : U-shaped, the teacher and the children are on the floor cushion. There is a \\
conversation about the book (what could be the title of the book? which characters could be in the book?) \\
The answers: Ayşe and her sister are flying kites-Fatma and Ayşe are walking around - Ayşe, her sister, the \\
$\operatorname{dog}$
\end{tabular}

CR5, T2, $17 \mathrm{~min}, 12 \mathrm{CHN}$ : The teacher is standing out, the children are sitting in the chair. There is a conversation about the story (who could be characters in the story?)

The answers: the wind, -shaking leaf, - the child gets his kite.

CR3, T2, 6 min, $12 C H N$ : U-shaped, the teacher and the children are sitting in the chair. There is a conversation about the book (what could be the title of the book?)

The answers: - kite in the air - the wind blew the children's toys. - weather condition -plane in the air-plane flying like a bird.

\section{While-story reading}

CR1, T1, $12 \mathrm{~min}, 11 \boldsymbol{C H N}$ : The teacher holds the books away, lean towards her sideways and reads it without an eye contact. She shows the page after reading the text.

Question: Do you know what swings the trees from one side to the other? The animals hide into the stacks of fallen leaves to escape from the cool wind. .... What could have happened later? The answers: -wind- there is no more answer

They are swinging, lying on the floor, standing up. Teacher: Come on, listen to the story! (warning for the speaking child) -Let's sit, -Emirhan! (warning for the child lying on the floor)

CR5 T2, $17 \mathrm{~min}, 12 \mathrm{CHN}$ : The teacher holds it a bit away from herself, tells them to keep silence and says that she will ask a question after the reading. She reads it without an eye contact, intonation or showing the pictures. She has a quite high tone. Some children approach her to look at the book, some play with their shoes or their friends' hair. She warns them by either calling their names or looking at them by emphasizing the words very loudly and exaggeratedly:

CR3, T2, 6 min, 12 CHN: The teacher holds it away from herself and in her sideways. She reads without an eye contact, looks at them and shows the pictures when the reading is over. She sometimes supports the text with 
the gestures.

Question: So, what does the wind work? (She answers herself: The seeds of the white tree fall into the ground and it creates new trees there)

Question: What caused the seeds of white tree to fall? The wind

Question: What is on this page? (by showing the page with the wind turbines), what happens there? (She answers herself: they are wind turbines, they produce electricity.)

Question: Well, what dries the clothes? The answers: the sun, -the wind

Comment: Although it is not windy here, there are the windy areas in various parts of the world. There is the wind as the earth rotates.

Question: Well, is the earth tired while rotating? (she comments herself: I don't know about it, let's leave it to our imagination)

The answers: -the wind -the boat sank in the sea -shattered ships- the weather is sometimes sunny, sometimes cold.

\section{After-story reading}

CR1, T1, $12 \mathrm{~min}, 11 \mathrm{CHN}$ : The teacher asks a question: who will tell what happened in our story? The answers: -there was a wind - the leaves of the tree flew, -the kite flew.

CR5 T2, 17min, 12 CHN: Question: -Yes, kids! what is the wind? -air

Question: can we see the wind? - feel it? -no -yes

Question: how do we feel it? - it gets cold- we notice that the leaves fly. - we feel when it hits us.

CR3, T2, 6 min, 12 CHN: Question: What is the story about? What happens after the wind?

The answers: -wind -boat sank in the sea -the ships were shattered - it is sometimes sunny, sometimes cold.

On the lake

Before-story reading

CR6, T1, 8 min, $14 \mathrm{CHN}$ : U-shaped, the teacher and the children are sitting in the chair. There is a conversation about the book (What could be the story about?) The answers: - frog

CR1, T2, 7 min, 6 CHN: U-shaped, the teacher and the children are sitting in the chair. There is a conversation about the book (what could be the title of the book? What could be the story about?)

The answers: - frog- kermit the frog - mother frog - dolphin -shark

While-story reading

CR6, T1, 8 min, 14 CHN: The teacher holds the book away from herself and reads it without an eye contact. There is no intonation. Her tone does not change according to the characters. She reads loudly.

Question: What will come out of the egg? The answers: - frog

Question: Why is it called "tadpole"? No answer.

CR1, T2, 7 min, 6 CHN:

The teacher leans over and reads the book. After reading, she moves it to the left and right and shows it to the children. She changes her tone and animates the characters.

Question: He felt a shadow on him.... What could have happened later? The answers: -shark, -ship

Teacher's comment: it becomes a tadpole.

After-story reading

CR6, T1, 8 min, 14 CHN: Question: what was the story about? Where is the frog live?

The answers: frog-tadpole-in the water- lake

Teacher: It had a name. Isn't it a lake?

CR1, T2, 7 min, 6 CHN: Who wants to tell it?

The answers: He tried to eat a big fish, -the tadpole grew up.

The rainy day

\section{While-story reading}


CR6, T1, 11 min, $14 \mathrm{CHN}$ :

The teacher holds the book in her lap, leans forward and reads it without an eye contact. She correctly intonates the repeated expressions. (it grows up, grows up, grows up...) Her tone does not change according to the character,

After reading, she shows the book all the class.

Question: Did you wonder why the clouds form? What was firstly there in the air? What happened later?

Later....

Yes- No

They are swinging in the chair, some are moving with the chairs.

Concentration: The teacher says, "let's look at this illustration" and shows it to the all class in order to concentrate them again.

Concentration: The story is not over. Let's see what could have happened later?

CR2, T1, 8 min, 12 CHN: Why does the rain occur? The answers: it is hailing-water-snow-water drop- it rained later.

Question: What happens after the rain? The answers: puddle

Question: What happens when there is both rain and sun? The answers: rainbow -

- Teacher, I saw a real rainbow

-me too, me too, me too ...

After-story reading

CR6, 1, 11 min, 14 CHN: Who wants to tell it?

Firstly, they are not attending. Then she asks by directly telling their names

The answers: - It rained -It became sunny.

CR2, T1, $8 \mathrm{~min}, 12 \mathrm{CHN}$ : We are having rainy days these days, right?

The answers: when the clouds collide, it rains. -we take our umbrella not to get wet $-\mathrm{I}$ once climbed to the balcony while raining and a real lighting struck.

How deep is the sea?

Before-story reading

CR4, T1, 13 min, 8 CHN: The teacher is in her chair, the children are kneeling one after the other. There is a conversation about a book (what could be the title of the book? what characters could be in the story?)

The answers: the little penguin wonders- the penguin travels in the sea- the fish swims- under the sea- the little penguin is looking for a fish to eat- pengi- seal

CR6, T8-1, 12min, 15 CHN: U-shaped, the teacher and children are in the chair. No conversation about the book.

While-story reading

CR4, T1, $13 \mathrm{~min}, 8 \mathrm{CHN}$ : The teacher holds it a bit away from herself, tells them to keep silence, says that she will ask questions after the reading, and reads it without an eye contact, intonation or showing the pictures. More importantly, she reads the book with curiosity imprecisely.

Question: -It jumped into the sea. What could he have asked the fish?

Question: What could be the whale's answer? (-teacher, I can't see)

Berk! Aral !(warning)

Question: The underwater vehicle crashed into the bottom. What could have happened later?

The answers: people can die- it was shattered- it was broken

- Teacher, did the story end?

They swing, want to leave the area, lie on the floor. They push each other, some are leaving the area.

Teacher: it is almost finished.

CR6, T8-1, $12 \mathrm{~min}, 15 \mathrm{CHN}$ : The teacher holds it away from herself and in her sideways and reads it. She shows the pictures after the reading. She adds feeling to the reading. There is intonation and stress. 


\section{After-story reading}

CR4, T1, 13 min, 8 CHN: The children are moving back and forth in the chair, talking to each other and asking the teacher whether it is over. The teacher: Ok, I'll ask a few questions and then it'll finish.

Question: Who was the main character? The answers: Pipkin

Question: How deep is the sea? The answers: very deep

- Teacher! I can't see.

Question: Who did he encounter last? The answers: -with a dog

Question: What colour was the underwater vehicle?

CR6, T8-1, 12min, 15 CHN:

Question: What did Pipkin most wonder? The answers: the bottom of the sea, how deep the sea is

Question: Are there things you wonder about? No answer

-There is very noise. I can't hear.

Question: What are you doing to learn things you wonder? No answer

Question: I cannot hear what Pipkin did. It is almost finished. No answer

Burcu and Berk: Safety looking out for yourself

Before-story reading

CR4, T1, 13 min, 8 CHN: The teacher is sitting in her chair, the children are kneeling one after the other. There is a conversation about the book (what could the title of the story? who could be in the story?)

The answers: -he is riding a bike- he is going to the sea- he is wearing a mask.

\section{CR5, T2, 17 min, 11 CHN:}

U-shaped, the teacher stands and walks in the class, the children are sitting in the chair. There is a conversation about the book (what could the title of the book?)

The answers: - Elif, her mother and father are swimming in the-she is swimming in the sea -Zeynep is going to the sea.

\section{While-story reading}

CR4, T1, 13 min, 8 CHN: The teacher holds it a bit away from herself, tells them to keep silence and says that she will ask a question after the reading. She reads it without an eye contact, intonation or showing the pictures. They move forward to see the book.

Teacher: -ok, go back to your place.

Question: - What did he forget? The answers:

-Teacher, I can't see.

-he didn't check your right and left-he can die- a car can crash (they want to maintain to guess but the teacher continues to read by saying "it is enough")

They swing, want to leave the area, lie on the floor, and push each other. Some of them are leaving the area.

A child asks if he can replace the object he finds on the floor.

Teacher: -stand up, please (warning for the child lying on the floor)

-sit down, please (warning for the child standing),

-we were quiet, right? -Fatma Nur, Ece! -are you listening to me?

-Seçkin, please (warning for the child lying on the floor) -do you listen to me?

-it's almost finished

- Seçkin, stand up I'm warning you last time

-Come on, do not go! It's almost finished (warning for the children who want to leave the area) ...

CR5 T2, $17 \mathrm{~min}, 11 \mathrm{CHN}$ : The teacher holds it towards herself without an eye contact. She stands and sometimes reads at some point, sometimes walks, sometimes shows pictures. She reads very loudly.

Question: What did he forget? (the first page) The answers: 
Yes, you're right (she gives feedback to their responses)

The children move in the chair, play with their slippers, swing, hug others, and asks whether the class is over. The teacher looks at them and continues to read with a louder tone.

\section{After-story reading}

CR4, T1, 13 min, 8 CHN: Question: Who were the characters in the story?

Question: What did they stay away from? -the scissor is dangerous

Question: What's the police phone number? -155

-The children ask whether it has finished, they are swinging back and forth in the chair and playing with their shoes.

CR5 T2, $17 \mathrm{~min}, 11 \mathrm{CHN}$ : Question: Who can tell what happened in the story?

The answers: -I'm thirsty - there was a dog and people.

\section{Tali becomes self-confident}

Before-story reading

CR2, T1, $9 \min , 15 C H N$ : U-shaped, the teacher and the children are sitting in the chair. There is a conversation about the book (what could be the title of the book?)

The answers: -rabbit, -Tali becomes self-confident

Teacher: she starts to read by saying "you know how to read."

CR6, T2, 8 min, 20 CHN: U-shaped, the teacher and the children are sitting in the chair. There is a conversation about the book (what could be the title of the story? who could be in the story?)

The answers: -rabbit, -Tali- other books of the series have been read in the class.

\section{While-story reading}

CR2, T1, 9 min, 15 CHN: The teacher holds the book away from herself in her sideways without an eye contact. She looks at the children when the reading is over.

Question: Which one is Tali?

CR6, T2, 8 min, 20 CHN: The teacher holds the book away from herself in her sideways without an eye contact. She looks at the children when the reading is over. She shows the pictures but everyone cannot see them. She changes her tone according to the characters.

Question: What did Tali's mother tell him?

The answers: something to cheer him up -eat carrot -you can play with the toy.

\section{After-story reading}

CR2, T1, 9 min, 15 CHN: Question: what was the story about?

The answers: he was drawing a picture - (they are joking with one another)

Question: Who were the characters in the story?

The answers:-mother-Tali-teacher-his friends

CR6, T2, 8 min, 20 CHN: Question: Why was Tali sad? -he couldn't score.

Question: What did her mother say? -you can draw a picture.

Question: what was he good at? -drawing

Question: Why is the dolphin crying? -since there is no sea.

Question: Well, what are you good at?

I am good at drawing a house.

-I am good at drawing picture.

-I am good at tidying my toys up.

-I am good at helping my father.

Comment: Yes, so we all are good at different issues.

Tali stands up for himself

Before-story reading 
CR6, T2, 8 min, 20 CHN: U-shaped, the teacher and the children are sitting in the chair. No conversation about the book.

CR5, T1, $10 \mathrm{~min}, 14 \mathrm{CHN}$ : U-shaped, the teacher and the children are sitting in the chair. There is a conversation about the book (what could be the title of the story? who's in the story?)

The answers: -mouse -toy - mouse -toy -rabbit -sister

While-story reading

CR6, T2, $8 \mathrm{~min}, 20 \mathrm{CHN}$ : The teacher holds the book in her sideways and reads it without an eye contact.

CR5, T1, $10 \mathrm{~min}, 14 \mathrm{CHN}$ : The teacher holds the book away from herself in her sideways and reads it without an eye contact. In the pre-reading, she shows the pictures to the children. No stress and intonation.

Question: ... He felt a glow of jealousy. Well, what could happen then?

The answers: he demolished the tower -they continued to work as a builder

(the teacher warns the children lying and shaking in the chair) Ayșe! Ahmet!

After-story reading

CR6, T2, 8 min, 20 CHN: Our story is over.

Question: Why did Rafiş demolish Tali's tower? -He envied Tali.

Question: How will you feel if someone demolishes your tower? -I'll get angry -I'll feel sad.

3. When the tower fell over, what was on Tali's mind? He thought of demolishing his tower.

Question: Why didn't do it? - he remembered the promise he had made to his teacher.

Question: What did Tali tell Rafiş?

The children are starting to move, do not answer (the questions in the last page of the book)

CR5, T1, $10 \mathrm{~min}, 14 \mathrm{CHN}$ :

Question: Do you encounter such things? They do not answer. The teacher asks some children by saying their name.

Question: Who can tell the characters in the story?

Question: Who were they? What happened? Who demolished the tower?

The children are moving away from the area.

Alper: I want to win all the time

Before-story reading

CR3, T2, $10 \mathrm{~min}, 10 \mathrm{CHN}$ : U-shaped, the teacher and the children are sitting in the chair. There is a conversation about the book (What is the title of the story?)

The answers: -trees, -stones

CR1, T1, $17 \mathrm{~min}, 11 \mathrm{CHN}$ : U-shaped, the teacher and the children are sitting on the beanbag. There is a conversation about the book (what is the title of the story? who's in the story?)

The answers: - Ayșe and Fatma went out with their dog,- there are two children: the one is next to his friend, the other is hiding,-Ali is with his friends, dog and cat,- cat,-dog,-Ayşe and Fatma

\section{While-story reading}

CR3, S2, $10 \mathrm{~min}, 10 \mathrm{CHN}$ : The teacher holds it away and in her sideways, does not make an eye contact, sometimes intonates and shows the pictures.

Question: He did not want to leave the game. Then what could have happened?

The answers: -he fought, -he won, he had cut his curly hair,-he said "I should win",-he jokingly clawed them.

CR1, T1, 17 min, 11 CHN: The teacher reads the book by holding it in her sideways and does not make an eye contact. There is no stress, intonation or gestures. She occasionally shows the pictures to the children.

Question: Alper was panting when he came to the door. Then what could have happened?

The answers: -he entered the house -his mother asked what happened, he said that they did not play with him- His mother requested the children to play with him.

Some children are standing, some are swaying. Two of them are hugging each other. The others are talking among themselves and lying on the floor. 
Teacher: Alper, Kerem take your place- kids! Ege Ege Ege... Gökçe, you too!

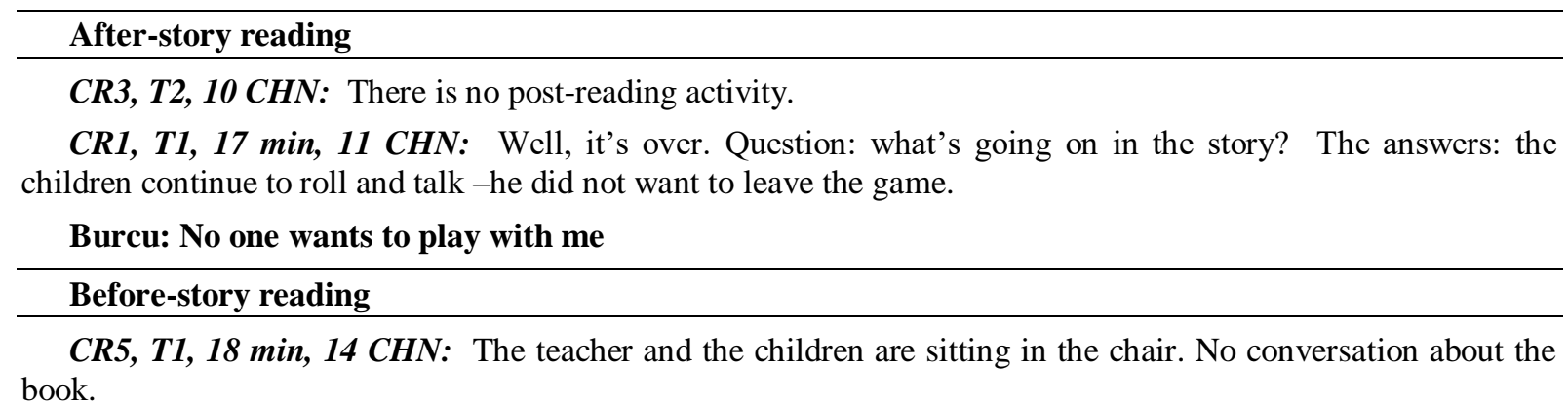

CR4, T2, 15 min, 10 CHN: The teacher is sitting in her chair, the children are kneeling one after the other. No conversation about the book.

While-story reading

CR5, T1, $18 \mathrm{~min}, 14 \mathrm{CHN}$ : The teacher makes an eye contact with the children by holding the book on her sideways. She shows the pictures and changes her voice tone according to the flow of the story.

Question: Can the parrot talk? I once saw a lamb in the zoo.

Question: Do you make friends with younger children, too? -yes

Question: Who would make friends with the little girl if he/she were Burcu? -me

CR4, T2, $15 \mathrm{~min}, 10 \mathrm{CHN}$ : The teacher reads the book by leaning forward and holding it in her lap, and does not make an eye contact. When the reading is over, she shortly looks at the children.

Question: Why did Burcu cry? The answers: they did not play with her- Teacher, I'm bored!

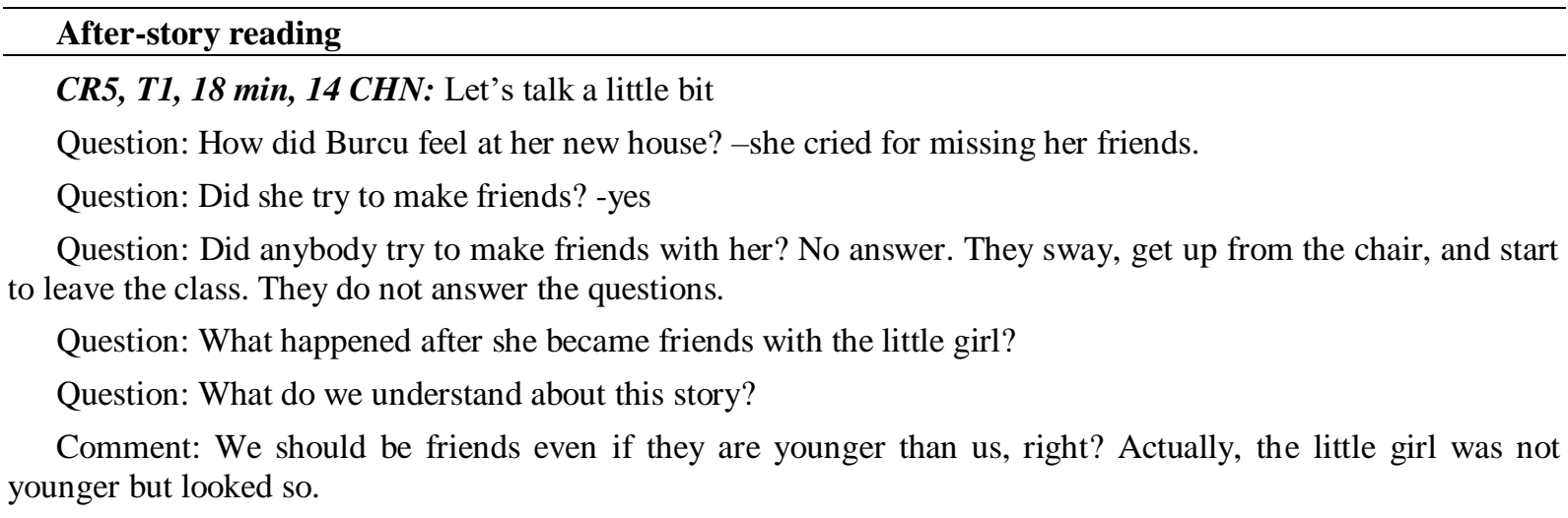

CR4, T2, $15 \mathrm{~min}, 10 \mathrm{CHN}$ : Question: What did you understand from the story? The answers: -I understood nothing

\subsubsection{Before story reading}

The video recordings showed that the children generally sit in a half-moon position on the child seat or cushions and the teachers sit in the middle of this order where all the children could see. Exceptionally, the teacher was standing, and the children were sitting on the floor cushions or in the chairs in a class; in another class, the teacher was sitting in her chair and the children were kneeling one after the other. It is understood that the children became distracted more in the class in which there were these seating arrangements. The teachers generally asked the questions by showing the book cover in the before-reading process "what could be the title of the book? What characters could be in the story? There was not any kind of activity such as a poem, finger game or rhyme. It is noteworthy that the teachers posed those questions in the pre-reading process of the informational books. 


\subsubsection{While story reading}

It is understood that the teachers and prospective teachers did not utilize from any supporting technique in the while-reading process, had a limited use of intonation according to the characters, gestures, mimics, and eye contact. They generally performed reading activities by reaching their arms out, holding the book in their sideways and leaning forward to read. Only a few teachers showed the pictures to the whole class after reading the text. In addition, most of the participants posed questions to the children what could have happened later? what did her mother tell? etc. It is noteworthy for the teachers to pose the question "what could have happened later?" when the events are not successive in the informational books. (The books "Burcu and Berk: Safety looking out for yourself and the wind").

\subsubsection{The case of attending the story and becoming distracted in while-reading process}

During the story-reading process, the children either moved back and forth, played with their legs, moved with their chairs, lay on the floor, rolled on the floor, hugged their friend, pushed their friends, talked with their friends, posed questions such as "I'm bored, when the lesson will finish", left the area or tried to draw attention to other issues. In order to avoid these behaviors, the teachers called their names stressed and aloud (Ali, Ayşe...) or warned them by some expressions " you make me sad, let's stand up, I'll not say it again- sit down please, it's almost finished, it's over...

The video recordings on two informational books (Burcu and Berk: Our emotions and Burcu and Berk: Safety looking out for yourself) revealed that the children lost their attention on the books more and it was not due to the teacher and the group. When these books were examined, it was understood that the information in the book was indirectly presented and it was incoherent. Besides, the flow of presentation was not well-structured and more than one piece of information in the same scope was presented at the same time. Therefore, the children could have had a concentration problem. The case of attending to the story or becoming distracted in other three informational books changed according to eye contact, teachers' tones, and the quality of the questions.

When the video recordings of the book entitled "The rainy day" were examined, it was observed that while the teacher asked, "who wants to tell the story?" in a group, the other teacher said, "we are having rainy days in these days, right?" in the other group. Whereas the children were reluctant and gave short answers such as "it rained, it became sunny" when the teacher called their names in the first group, the others made sentences including their own lives and experiences such as "I climbed to the balcony when it was rainy, the lightning struck" after the teacher's expression in the second group. In narrative books, the children become distracted less that is potentially connected with reading properties such as sitting position, teachers' tones, and eye contact. When we examined the video recording of the book entitled "how deep is the sea?", it was seen that the children said "Teacher, I can't see" in the beginning of the reading activity in the group where they sit back to back, they pushed their friends to see and approach the teacher.

\subsubsection{After story reading}

It was observed that the teachers asked the children to tell the story or posed questions to recall the characters, events, and the places (who wants to tell it? where did the frog live? what did Pipkin most wonder?) In addition, they finitely utilized from the questions which enable the children to associate subjects and concepts in the story with their lives (What are you good at? Did you have such feelings?). 


\section{Discussion and Conclusions}

This study examined the use of the picture books in the preschool education institutions, asked the teachers' opinion on the story. It aimed at getting a clear-cut picture on the use of the books in the preschool classes by analyzing the story-reading practices of the teachers.

The findings obtained from the examination of the books in preschool education classes showed that the libraries in the classes mainly consisted of the book sets and the tales (fables, Keloglan tales, and classics). The book sets of included books written by a specific author or multiple authors by considering specific concepts and issues. According to Şirin (1994), the tales, especially fables, are didactic and informative in which goodness is praised, badness is punished (Ar1c1, 2015). Since the books examined in this study mainly consisted of tales and book sets, the teachers paid attention to the content (topics, informative feature) rather than literary, aesthetic, language and visual aspects in book selection. Some research findings in the literature also showed that the teachers primarily considered content and educational aspect of the book (Turan \& Ulutaş, 2016). However, one of the fundamental functions of the children's literature is to give them a love of reading as well as contributing to their learning. Except for the informational books which directly give information on science and natural events, it should be essential to raise awareness instead of didactic quality in the children's books. In addition, the picture books with artistic features contribute to lead the children's attention to the books and improve listening skills. The books which are written on the basis of an artificial teaching can negatively affect the relationship between the book and the children and thereby the love of books (Sever, 2013). All the teachers (except for one) in this study stated the books contributed to the children's cognitive and social-emotional development.

Gönen, Ünüvar, Bıçakcı, Koçyiğit, Yazıcı, Orçan, Aslan, Güven \& Özyürek (2010) similarly found that the teachers emphasized at least the role in giving the love of books and habit of reading while lecturing the importance of Turkish-language activities. In another study, the teachers stated that reading stories to the children contributed at least to the affection of love for books. (Ergül, Karaman, Akoğlu Tufan, Dolunay-Sarıca \& Bahap-Kudret, 2014). In contrast, in addition to the educational aspects and developmental contribution, it is particularly important the children's books to give a chance to meet with literary and artistic work and give the love of books (Gönen \& Veziroğlu, 2013). In this research selection of books by teachers for their classes was revealed to involve four criteria of topic and content (language used, instructional, topic, content, appropriate for the program), visuals, form characteristics (page number, paper quality, size of book, size of text, writing-picture ratio) and development characteristics of children (age, development). Considering the books found in classes, it can be said that children's development is paid more attention. The research findings of Donovan and Smolkin (2001) introduced four categories on the book selections of the teachers. They were as follows: content, visual features, readability concerns, suitability for the class/developmental level, and genre (whether it includes entertainment and pleasure). In another study, the teachers stated that they paid attention to children's point of view and content of the book (Hsiao \& Chang, 2016).

In this study, participating teachers mostly considered the books in their classrooms were not sufficient and stated they required more books related to science in addition to the available books. It is noteworthy that the books requested by teachers were books containing information about certain topics. This finding can be interpreted that while the teachers considered books as a means for teaching, they did not pay attention to the aspects of literary, aesthetic and planting in love of books. The findings of this study ascertain that they ignored the features such as author, illustrator, language, and style.

In addition, the activities they specified in the interview form regarding the story reading practices (using different methods; poems, finger games or conversation in pre-reading; dramatization etc. the in 
post-reading) were not observed in the video recording. The data obtained from the story reading videos showed that the teachers did not perform any activity (poem, finger game, rhyme, and conversation) and use any support material for reading. Most of the teachers posed the questions "what could be the title of the story? What characters could in the story?" in the pre-reading process. The research on examining while-reading activities of the preschool teachers revealed that they drew attention to the story by talking about the book cover, asking the title of the book, and asking questions about the book cover (Işıkoğlu Erdoğan et al., 2016). In this study, it was found that the teachers finitely showed the pictures in the books, asked questions about the page they read and requested them to guess what would happen in the next page. In addition, they made a limited eye contact while reading and did not change their tone according to the characters or the events. In the while-reading, showing the pictures to the children and reading the book to the small group rather than the whole class will keep the children's attention on the book alive (Işitan, 2013). The activities such as stopping to read the book in the important parts of the book, asking them to guess what will happen on the next page or reading the book by changing their tones according to the characters will be an example for the children in using the appropriate tone of voice when asking questions or telling the characters in a similar way (Morgan, 2009). As well as asking questions at the different levels in the post-reading (remembering, understanding, applying, evaluating), including artistic activities, dramatization or book-creating activities will increase the outputs of the children's storybooks (Işitan, 2013). Another remarkable finding from the story reading videos was that the teachers merely asked the questions "who will tell the story? what happened in the story? whom did Pipkin meet? do you have such feelings? etc." and did not perform any different activity. The researches in the literature manifested that the teachers generally posed questions to the children in the post-reading and asked them to tell/summarize the story and discuss it (Gönen et al. 2010; Turan \& Ulutaş, 2016). Since different methods are not used in the story reading activities, the teachers follow a monotonous discourse which causes distraction and boredom of the books (Olgan, 2013).

The findings obtained in this research found that children display excessive distracted behavior during reading activities (rocking, leaving the area, pushing friends, rolling on the ground, etc.). It is understood that children displayed more distracted behavior during reading of informative books compared to narrative books. These findings may be associated with the plan, language used or visuals in some informative books, along with the strategies used by teachers during reading in general (tone of voice, eye contact, way of holding the book and children's seating pattern, etc.). Another noteworthy finding in this study is that teacher's descriptions of how they perform reading activities in class with children do not overlap with the behavior displayed during the reading performance.

This study primarily focused on the video recordings of the story readings of the books selected by the researchers. Therefore, it did not examine the teachers' individual readings on the books they selected themselves into their personal library. It can be considered as a limitation of the study. The further studies can examine the routine readings of the teachers and the books read in these readings.

\section{References}

Arıcı, A. F. (2015). Hayale dayalı türler. In Ö. Yılar and L. Turan (Ed), Eğitim Fakülteleri Için Çocuk Edebiyati (pp.118-199). Ankara: Pegem.

Bağcı Ayranc1, B., \& Aytaş, G. (2017). Preschool teacher candidates' views on functionality of child literature in education. Journal of Human Sciences, 14(4), 4226-4240.

doi:10.14687/jhs.v14i4.5093 
Bailey, A. R. (2009). Early essentials: Developing and sustaining birth-kindergarten library collections. Children and Libraries, 7, (3), 17-20.

Bay, D. N., \& Çetin, Ö. Ş. (2014). Storybook reading strategies of preschool teachers in the USA and Turkey. International Journal of Education and Research, 2(7), 41-54.

Beaty, J. J. (2009). Early childhood literacy strategies. Upper Saddle River, New Jersey, Columbus, Ohio: Pearson.

Çer, E. (2016). Preparing books for children from birth to age six: the approach of appropriateness for the child. Journal of Education and Practice, 7(6), 78-99.

Dağlıoğlu, H. E., \& Çamlıbel-Çakmak, Ö. (2009). Okul öncesi çocuklarına yönelik yayınlanan hikâye kitaplarının şiddet ve korku öğeleri açısından incelenmesi. Türk Kütüphaneciliği, 23(3), 510-534.

Deniz, A. (2018). Resimli öykü kitaplarının ve kitap okuma etkinliklerinin niteliğ̈inin beş yaş çocuklarının dil gelişimiyle iliş̧isinin incelenmesi (Unpublished Doctoral Thesis). Hacettepe Üniversitesi, Eğitim Bilimleri Enstitüsü, Ankara.

Dilek, A. (2017). The examination of toys used in illustrated children's books. Journal of Early Childhood Studies, 1(1), 81-93.

Donovan,C. A., \& Smolkin, L. B. (2001). Genre and other factors influencing teacher's book selection for science instruction. Reading Research Quarterly, 36(4), 412-440.

Duke, N. K., \& Kays, J. (1998). Can I say "Once upon a time?": Kindergarten children developing knowledge of information book language. Early Childhood Research Quarterly, 13(2), 295-318.

Ergül, C., Karaman, G., Akoğku, G., Tufan, M., Dolunay-Sarıca, A., \& Bahap- Kudret, Z. (2014). Early childhood teachers' knowledge and classroom practices on early. Elementary Education Online, 13(4), 1449-1472.

Ergül, C., Akoğlu, G., Sarıca, D. A., Tufan, M., \& Karaman, G. (2015). Ana sinıflarında gerçekleştirilen birlikte kitap okuma etkinliklerinin "etkileşimli kitap okuma" bağlamında incelenmesi. Mersin Üniversitesi Ĕ̈itim Fakültesi Dergisi, 11(3), 603-619

Garzotto, F., Paolini, P., \& Sabiescu, A. (2010). Interactive storytelling for children. Retrieved from http://hoc.elet.polimi.it/idc/2010/assets/doc/Interactive_storytelling_Workshop_IDC2010.pdf.

Goins, S. L. (2004). Botany in children's literature: A content analysis of plant-centered children's Picture books that have plot and characters (Unpublished Doctoral Thesis) Lousiana State University, the USA.

Gönen, M. (1993). Anaokulu öğretmenlerinin 5-6 yaş çocukları için kullandıkları masal ve hikaye kitaplarının niteliklerinin incelenmesi, Türk Kütüphaneciliği, 7(2), 83-88.

Gönen, M., \& Arı, M. (1989) Anaokuluna giden dört-beş yaş çocuklarına resimli kitaplarla yapılan eğitimin dil gelişimine etkisinin incelenmesi. Ĕgitim ve Bilim, 1(13), 21-30.

Gönen, M., Uludağ, G., Fındık Tanrıbuyurdu, E., \& Tüfekçi, E. (2014). The examination of children's picture books' features for 0-3-year-olds. Hacettepe University Journal of Education, 29(1), 126139

Gönen, M., Ünüvar, P., Bıçakçı, M., Koçyiğit, S., Yazıcı, Z., Orçan, M., Aslan, D., Güven, G., \& Özyürek, A. (2010). Study of how preschool education teachers implement language activities Mehmet Akif Ersoy Üniversitesi Eğitim Fakültesi Dergisi, 10(19), 23-40. 
Gönen, M., \& Veziroğlu, M. (2013). Çocuk edebiyatının genel hedefleri. In M. Gönen (Ed.), Çocuk Edebiyati (pp.1-12). Ankara: Eğiten Kitap.

Gönen, M. (2013). Cumhuriyet öncesi ve Cumhuriyet döneminde okul öncesi çocuk edebiyatı. In M. Gönen (Ed.), Çocuk Edebiyatı (pp.15-32). Ankara: Eğiten Kitap.

Gönen, M., \& Veziroğlu, M. (2013). Çocuk edebiyatının genel hedefleri. In M. Gönen (Ed.), Çocuk Edebiyatı (pp.1-11). Ankara: Eğiten Kitap.

Gönen, M., Uludağ, G., Fındık Tanrıbuyurdu, E., \& Tüfekçi, E. (2014). The examination of children's picture books' features for 0-3-year-olds. Hacettepe University Journal of Educatioan, 29(1), 126139

Hannibal, M. A.Z., Vasiliev, R., \& Lin, Q. (2002). Teaching young children basic concepts of geography: A literature-based approach. Early Childhood Education Journal, 30 (2), 81-86.

Hsiao, C.-Y., \& Chang, Y.-M. (2016). A study of the use of picture books by preschool educators in outlying Islands of Taiwan. International Education Studies, 9(1), 1-19. http://dx.doi.org/10.5539/ies.v9n1p1

Işıtan, S. (2013). Kitap okuma modelleri ve öykü sonrası etkinlikler. In M. Gönen (Ed.), Çocuk Edebiyati (pp.251-262). Ankara: Eğiten Kitap.

Işıkoğlu-Erdoğan, N., \& Akay, B. (2015). Okul öncesi eğitimde hikaye okuma ve öğretmen sorularının incelenmesi. Mehmet Akif Ersoy Üniversitesi Ĕ̈itim Fakültesi Dergisi, 36, 34-46

Iş1tan, S. (2016). Illustrated storybooks for preschool children published in Turkey between 1980 2013: A study based on preschool education reforms. Educational Sciences: Theory \& Practice, 16, 669-690.

Işıkoğlu Erdoğan, N., Atan, A., Asar, H., Mumcular, F., Yüce, A., Kiraç, M., \& Kilimlioğlu, Ç. (2016). Examination of parents' and teachers' shared reading activities. Elementary Education Online, 15(1), 125-135.

İpek-Yükselen, A. (2013). Okul öncesi çocuk kitaplarının tanıtımı. In Mübeccel Gönen (Ed.), Çocuk edebiyatı (pp. 57-75). Ankara: Eğiten Kitap.

Keat, J. B., \& Wilburne, J. M. (2009). The impact of storybook on kindergarten children's mathematical achievement and approaches to learning. US-China Education Review 6 (7), 61-67.

Kılıç, Z., Değirmenci, Ş.,İ Ünsal, F.Ö., \& Uyanık-Balat, G. (2017). Okul öncesi dönem çocuklarına yönelik resimli çocuk kitaplarında yer alan temel kavramların incelenmesi. Mehmet Akif Ersoy Üniversitesi Eğitim Fakültesi Dergisi, 44, 424-441.

Kindle, K. J. (2001). Same book, different experience: A comparison of shared reading in preschool classrooms. Journal of Language and Literacy Education, 7(1), 13-34.

Körükçü, Ö., Acun-Kapıkıran, N., \& Aral, N. (2016). Schwartz'1n modeline göre 3-6 yaş resimli çocuk kitaplarında değerlerin incelenmesi. Mehmet Akif Ersoy Üniversitesi Ĕ̈itim Fakültesi Dergisi, 38, 133-151.

Mantzicopoulos, P., \& Patrick, H. (2011). Reading picture books and learning science: Engaging young children with informational text. Theory into Practice, 50, 269-276.

MEB (2013). Okul öncesi eğitimi programı. Millî Eğitim Bakanlığı Talim Terbiye Kurumu.

Merriam, S. B. (2013). Nitel araştırma: Desen ve uygulama için bir rehber. (S. Turan, Trans). Ankara: Nobel Yayın Dağıtım. 
Morgan, H. (2009). Picture book biographies for young children: a way to teach multiple perspectives. Early Childhood Education Journal, 37, 219-227. doi:10.1007/s10643-009-0339-7.

Moschovaki, E., Meadows, S., \& Pellegrini, A. (2007). Teachers' affective presentation of children's books and young children's display of affective engagement during classroom book reading. European Journal of Psychology of Education, 12(4), 405-420.

Olgan, R. (2013). Hikaye kitabı ve farklı modeller kullanarak öykü anlatım yöntemleri. In M. Gönen (Ed.), Çocuk Edebiyati (pp.239-250). Ankara: Eğiten Kitap.

Pentimonti, J., Zucker, T., \& Justice, L. (2011). What are preschool teachers reading in their classrooms? Reading Psychology, 32, 197-236.

Reese, D. A., \& Harris, V. J. (1997). "Look at this nest!" The beauty and power of using informational books with young children. Early Childhood Development and Care, 127, 217-231.

Robertson, S-J. L., \& Reese, E. (2017). The very hungry caterpillar turned into a butterfly: Children's and parent's enjoyment of different book genres. Journal of Early Childhood Literacy, 17(1), 3-25.

Rodriguez, M. C. (2013). Fiction and Non-Fiction Books for Bilingual Preschool Readers retrieved from http://www.uh.edu/honors/honors-and-the-schools/houston-teachers-institute/curriculum-nits pdfs/2003/twentieth-century-novels/rodriguez-03-kid-lit.pdf

Sackes, M., Trundle, K. C., \& Flevares, L. M. (2009). Using children's literature to teach standardbased science concepts in early years. Early Childhood Education Journals, 36, 415-422.

Saracho, O. N., \& Spodek, B. (2010). Families selection of children's literature books. Early Childhood Education Journal, 37, 401-409.

Sever, S. (2003). Çocuk ve edebiyat. Ankara: Kök Yayıncılık.

Şimşek, Z. C. (2017). Farklı kitap okuma tekniklerinin 48-66 ay grubu çocuklarının dil gelişimine olan etkileri (Unpublished Doctoral Thesis) Pamukkale Üniversitesi, Denizli.

Tarım, Ş. D. (2015). Examining reading alouds in preschool education classrooms in Turkey. International Journal of Social Science Studies, 3(6), 79-86.

Temizyürek, F., Şahbaz, N.K., \& Gürel, Z. (2016). Çocuk edebiyatı. Ankara: Pegem.

Tetik, G. (2015). Diyaloğa dayalı hikâye okuma tekniği ile okunan öykülerin 4-5 yaş (48-60 ay) çocuklarının dil gelişimine etkisi (Unpublished master's thesis). Pamukkale Üniversitesi, Denizli.

Torr, J., \& Clugston, L. (1999). A comparison between informational and narrative picture boks as a context for reasoning between caregivers and 4 -year -old children. Early Child Development and Care. 159, 25-41.

Tuğrul, B., \& Feyman, N. (2006). Okul öncesi çocukları için hazırlanmış resimli öykü kitaplarında kullanılan temalar. Ankara Üniversitesi Eğitim Bilimleri Fakültesi 2. Ulusal Çocuk ve Gençlik Edebiyatı Sempozyumu (pp. 387-392). Ankara: Ankara Üniversitesi Yayınları, No:203.

Turan, F., \& Ulutaş, İ. (2016). Okul öncesi eğitim kurumlarındaki resimli hikaye kitaplarının özellikleri ile öğretmenlerin bu kitapları kullanma durumlarının incelenmesi. Hacettepe Üniversitesi Eğitim Bilimleri Enstitüsü Eğitim Araştırmaları Dergisi, 2(1), 21-45.

Tüfekçi-Can, D. (2014). Çocuk edebiyatı: Kuramsal yaklaşım. Ankara: Eğitim Kitapevi.

Ural, S. (2013). Okul öncesi çocuk kitaplarının tanıtımı. In M. Gönen (Ed.), Çocuk Edebiyati (pp.3355). Ankara: Eğiten Kitap. 
Wasik, B., \& Bond, M. A. (2001). Beyond the pages of a book: interactive book reading and language development in preschool classrooms. Journal of Educational Psychology, 93(2), 243-250.

Yılar, Ö. (2015). Cumhuriyet öncesi ve Cumhuriyet döneminde okul öncesi çocuk edebiyatı. In M. Gönen (Ed.), Çocuk Edebiyatı (pp. 37-68). Ankara: Pegem.

Yıldırım, A., \& Şimşek, H. (2013) Sosyal Bilimlerde Nitel Araştırma Yöntemleri. Ankara: Seçkin yayincilik.

Yükselen, A., Yumuş, M., \& Işık, E. (2016). The preschool educators' views about the criteria for selecting children's book. Başkent University Journal of Education. 3(2), 161-168.

Zucker, T. A., Cabell, S. Q., Justice, L. M., Pentimonti, J. M., \& Kaderavek, J. N. (2013). The role of frequent, interactive prekindergarten shared reading in the longitudinal development of language and literacy skills. Developmental Psychology, 49(8), 1425-1439.

\section{Okul öncesi eğitim kurumlarında hikâye kitaplarının kullanım durumlarının incelenmesi}

\section{$\ddot{O} z$}

$\mathrm{Bu}$ araştırmanın amacı okul öncesi eğitim sınıflarında resimli kitapların kullanım durumlarını incelemektir. Araştırmada nitel araştırma durum çalışması deseni kullanılmıştır. Veriler video kaydı, yarı yapılandırılmış görüşme ve dokümanlar kullanılarak toplanmıştır. Verilerin analizinde doküman analizi ve betimsel analiz teknikleri kullanılmıştır. Araştırma bulguları sınıflarda bulunan kitapların genellikle set halindeki öykü kitapları ve masallardan oluştuğunu ortaya koymaktadır. Bu çalışmaya katılan öğretmenlerin çoğu sınıflarındaki kitapların yeterli olmadığını düşündüklerini ve sınıflarında mevcut kitaplara ek olarak daha çok fen ve doğa ile ilgili kitaplar olması gerektiğini belirtmiştir. Araştırmanın en dikkat çekici bulgusu öğretmenlerin hikaye okuma sırasında çocuklarla sınırlı bir şekilde göz kontağı kurmaları, karaktere göre ses tonlarını ayarlamamaları ve hikaye okumayı bitirdikten sonra çocuklara hikaye ile ilgili soru sorma dışında bir etkinlik gerçekleştirmemeleridir.

Anahtar sözcükler: resimli çocuk kitabı, okul öncesi, çocuk, öğretmen, hikâye okuma

\section{AUTHOR BIODATA}

Burcu Özdemir BECEREN is an assistant professor in the Preschool Teacher Education Department at Çanakkale Onsekiz Mart University, holding an MA in Curriculum and Instruction and PhD in Preschool Teacher Education. Her main interest areas are teacher education, social and emotional learning, values education, and temperament in children.

Atiye ADAK OZDEMIR is working as an assistant professor at Pamukkale University, Preschool Teacher Education Department Denizli/Turkey. She holds a PhD in Preschool Teacher Education from Marmara Universty. Her main research interests are play, math and children literature in early childhood.

Filiz HIDIR is working as an instructor at Pamukkale University, Preschool Teacher Education Department Denizli/Turkey. Her main research interests are play and emotion regulation in early childhood. 